\title{
ANAESTHETIC PROBLEMS DUE TO DRUG ABUSE AND DEPENDENCE
}

\author{
LEONARD C. JENKINS, B.A., M.D., C.M., F.R.C.P.(C) ${ }^{\circ}$
}

THE TERM DRUG ABUSE may be used to refer to the use, usually by self-administration, "of any drug in a manner that deviates from the approved medical or social patterns within a given culture". ${ }^{1}$ Facets of drug abuse may be defined as follows:

\section{Definitions}

\section{(A) Physical Dependence}

A state created by constant administration of a drug in which presence of the drug in the body is necessary for normal functioning. ${ }^{2}$ It refers to an altered physiological state brought about by this repeated exposure to the drug which requires continued administration to prevent the appearance of a characteristic specific illness, called an abstinence or withdrawal syndrome. ${ }^{3}$

Physical dependence could be regarded as a medical complication of non-medical use of drugs since, in moderate to severe grades, it requires treatment. Its importance, however, is far greater than a mere complication, since its presence forces the individual into continuous rather than intermittent drug use. Physical dependence is a real physiological disturbance involving the central nervous system (CNS) that is not psychogenic. It is a self-limited, teversible process that will disappear if the drug is taken away.

Two types of physical dependence are established - the opiate type and the alcohol-barbiturate type. A great deal is known about the neurophysiological mechanisms underlying these two types. Two other types - the morphine agonistantagonist and the amphetamine types - are somewhat questionable.

(B) Habituation (Psychic Dependence) $)^{1-3}$

A situation in which a person desires and becomes accustomed to a drug but is not physically dependent upon it. It is a compulsion, arising from repeated exposure to a drug. There is a desire to continue use of the drug to obtain pleasure or to avoid discomfort, either physical or psychological.

\section{(C) Tolerance ${ }^{2, s}$}

A state in which the body tissues become accustomed to the presence of a drug and fail to respond to concentrations ordinarily effective; increased quantities are then necessary to produce the desired effect. There is thus a diminishing effect on repetition of the same dose of a drug or, conversely, a need to increase the dose to attain the initial degree of effect.

-Professor and Head, Department of Anaesthesia, Foculty of Medicine, University of British Columbia. Director, Department of Anaesthesia, Vancouver General Hospital. 
Two mechanisms of tolerance are known. ${ }^{3}$ The first is biochemical tolerance, which is due to more rapid detoxification of the drug by enzymatically mediated reactions, so that the drug is converted more quickly to more water-soluble compounds that are excreted and which usually have very low pharmacological activity. This form of tolerance is due to induction of increased amounts of oxidative enzymes in the liver microsomes, and is not specific to a certain drug, since induction of the enzymes by one drug will also increase the rate at which other drugs altered by the same kind of reactions are metabolized. ${ }^{4}$

The second mechanism of tolerance is tissue tolerance. This term refers to the ability of the organism to function in spite of concentrations of drug that originally caused marked impairment of function. The mechanisms are unknown adaptive changes within the tissue systems affected. ${ }^{3}$

It is interesting that tissue tolerance to morphine has been reported to be blocked by administration of inhibitors of protein synthesis, such as actinomycin- $\mathrm{D}^{\mathbf{5}}$ and cycloheximide, ${ }^{b}$ and that serum of tolerant animals when injected into non-tolerant animals both enhances and reduces the response of the non-tolerant animal to the drug. ${ }^{7}$ Tissue tolerance in the nervous-system has also been hypothesized to be duc to the presence of accessory paths within the CNS which normally are quiescent. When the main functional pathways are impaired by a drug, these parallel pathways, which are not affected or less affected by the drug, begin to function and, on repeated exposure hypertrophy in a functional sense, thereby accounting for tolerance and physical dependence. ${ }^{8}$

Still another hypothesis is that depressant drugs cause partial functional denervation of neurones throughout the central nervous system and these neurones, like denervated effector sites in the periphery, become hypersensitive."

\section{(D) Addiction}

This is a combination of physical dependence, habituation and tolerance.

Currently the term non-medical use of drugs has been adopted in preference to the older terms addiction or drug dependence. The reason usually given for this is that non-medical use of drigs is a neutral term with no connotation of good or bad. ${ }^{3}$ The phrase was adopted by the Canadian Government in establishing their Commission of Inquiry into the non-medical use of drugs. ${ }^{10}$ This Commission defined medical use as drug use indicated for generally accepted medical reasons, whether under medical supervision or not. Non-medical use, refers to use not for generally accepted medical reasons. Non-medical use can bo either legal or illegal. The use of alcohol by adults is non-medical but legal; the use of marihuana, in contrast, is both non-medical and illegal.

\section{Prevalenge of Drug Anuse (Non-Mrdical Drug Use)}

Drug abuse is no longer a matter involving chiefly a small number of persons living in big-city shelters under deprived socio-economic conditions. Non-medical use of drugs has spread widely among high-school and college students in both large and small cities. An increasingly serious problem exists.

It is believed that 12 million to 20 million Americans have tried marihuana. It 
is known that more than casual non-medical drug use rarely involves only one drug. Most drug dependent persons who come to medical attention are using or have used several drugs. ${ }^{3}$

The exact number of drug abusers in Canada is not known. The number of nonnarcotic drug abusers, including persons addicted or habituated to sedatives, stimulants, related drugs and certain tranquilizers, can only be roughly estimated. Probably more than 8 per cent or 10 per cent of high-school students have used marihuana. ${ }^{11}$ Some studies have found much higher proportions. At the University level current data suggest that more than 25 per cent of students have at least experimented with marihuana. ${ }^{10}$

Reports from law enforcement agencies are recognized as minimal reflections of the prevalence of drug abuse. The officially recorded number of narcotic addicts in Canada for 1969, the most recent year for which figures are available, was 4,060. The Division of Narcotic Control reported 5,157 marihuana cases in 1969,12

The anaesthetist can anticipate an increasing incidence of these types of patient presenting for surgery.

\section{The lueading Causes of Death Associated with Drug Abuse}

One extreme index of prevalence and type of non-medical use of drugs is an analysis of mortality rates related to these patients. Helpern and Rho ${ }^{13}$ have summarized the leading causes of death among addicts, based on autopsy reports of 1,561 addicts in 1966 in New York (Table 1).

TABLE I

Leading Causes of Death Amonc Adpicts

\begin{tabular}{lc}
\hline \multicolumn{1}{c}{ Causes } & $\begin{array}{c}\text { Percentage of } \\
\text { total deaths }\end{array}$ \\
\hline Acute reaction to dosage or overdosage & 48 \\
Narcotism and alcoholism & 20 \\
Tetanus & 8.3 \\
Pyogenic septic infection incladint endocarditis & 8.1 \\
Chronic narcotic addiction & 3.4 \\
Viral hepatitis & 1.9 \\
Miscellaneous & 20.3 \\
\hline
\end{tabular}

Although the toxicity of the drug itself is important ( 58 per cent of total deaths), the intravenous or even subcutaneous injection in itself may be of more importance regardless of the kind of drug. For instance, infectious complications of non-medical drug use - hepatitis, ${ }^{14}$ tetanus, bacterial endocarditis ${ }^{15}$ may account for one-third of the deaths. The "mysterious" deaths from "overdose" of heroin in New York City are now the leading causes of death in young males between the ages of 15 and 30 . More than 100 such deaths are anticipated this year in New York City. ${ }^{3,13}$

An extreme of drug abuse is suicide.

Suicide attempts in Vancouver, B.C., where drug-overdoses have been the method of choice are interesting and give some idea of the prevalence and accessibility of drugs. Table II summarizes known suicide attempts in Vancouver during 
TABLE II

SUICIDE Attempts VANCOUVER-JULY, 1969-February, 1970 DRUG OVERDOSES-TYPE

\begin{tabular}{lcc}
\hline \multicolumn{1}{c}{ Types } & Number & Percentage \\
\hline Sedatives-barbiturates & 126 & 22.2 \\
Analgesics (222, 292 Darvon) & 98 & 17.2 \\
Tranquilizers-Minor (Equanil, Librium, Diazepam) & 84 & 14.8 \\
Tranquilizers-Major (Laargactil, Spatine, Stelazine) & 51 & 9.0 \\
Sedatives-(Non-barbiturate-Nodular, Placidyl, Doriden) & 45 & 7.9 \\
Anticonvulsants (Dilantin, Mysoline) & 11 & 2.0 \\
Antidepressants (Tricyclics) & 8 & 1.4 \\
Other (Diet pills, Co, Diuretics, Poisons) & 40 & 18.0 \\
Unknowi & 105 & 100 \\
\hline
\end{tabular}

the period July, 1969 to February, 1970. During this time there were a total of 568 . Of these 196 were male, and 372 were female. ${ }^{10}$

In Table II note that 70 per cent of attempted suicides with drugs involve the sedative-(barbiturate and non-barbiturate)-analgesic-tranquilizer group. Barbiturates and tranquilizers are about equal in popularity ( 23 per cent each) as the most common drugs in suicide attempts. It is significant that 27.8 per cent of the suicide attempt population was reported to be in some degree of acute alcohol intoxication at the time of admission. ${ }^{16}$ Twenty-five per cent were under the influence of alcohol at the time of their death in the successfully completed suicide.

The central nervous system stimulants (e.g. amphetamines) do not have a high incidence of use in attempted suicides in Vancouver.

\section{Drugs Most Frequently Abused}

Smart and co-workers ${ }^{17}$ surveyed a group of 6,890 Toronto students in 1970 . Table III records the proportion in per cent of this group who used each drug at least once in the preceding six months.

Table IV classifies important drugs used non-medically, ${ }^{8,18}$ common to all age groups.

TABLE III

Drugs Most Frequentey Aeused

\begin{tabular}{lc}
\hline \hline \multicolumn{1}{c}{ Drug used } & $\begin{array}{c}\text { Percent of studeuts } \\
\text { using in } \\
\text { (Grades 7-13) }\end{array}$ \\
\hline Marihtuana & 18.3 \\
Glue & 3.8 \\
Other solvents & 6.3 \\
Barbiturates & 4.3 \\
Opiates & 4.0 \\
"Speed" & 4.5 \\
Stimulants & 6.7 \\
Tranquilizers & 8.8 \\
L.S.D. & $\mathbf{8 . 5}$ \\
Other hallucinogens & 6.7 \\
\hline
\end{tabular}


TABLE IV

Classtfication of Drugs Used Non-Medicalty

I. DRUGS CAUSING SEVERE PSYCHIC AND PHYSICAL DEPENDENCE (CNS DEPRESSANTS)

(A) Opiate or Morphine Type:

(1) Morphine and its congeneres: diacetylmorphine (heroin(B)

(2) Morphinana (Levo-Dromoran(A)

(3) Benzazocine: Pheazocine (Prinadol@)

(4) Meperidines: Meperidine (Demeroli

(5) Methadone and congeners

(B) Alcohol-Barbilurate Type:

(1) Ethyl alcohol

(2) Barbiturates

(3) Paraldehyde

(4) Chloral hydrate

(5) Meprobamate (Equanilß, Miltownß)

(6) Piperidenediones: glutethimide (Doriden()

(7) Benzodiazepines: Chlordiazepoxide (Librium(B), Diazepam (Valium(1)

(8) Ethinamate (Valmid()

(9) Ethchlorvynol (Placidyl(G))

II. DRUGS CAUSING STRONG PSYCHIC DEPENDENCE BET ONLY MILD OR QUESTIONABLE PHYSICAL DEPENDENCE:

(A) Opiale Agonist-Aniagonisl Type:

(i) Morphine Antagonists: Nalorphine (Nalline(8)

(2) Morphinan Antagonists: levallorphan (Lorfan(B)

(3) Banzazocine Antagonists: cyclazocine, pentazocine (Talwin(B))

(B) Amphetamine Type: (CNS Stintulants)

(1) Amphetamines

(2) Piperidines: methylphenidate (Ritalin(i))

III. DRUGS CAUSING PSYCHIC DEPENDENCE ONLY (CNS STIMULANTS):

(A) Cocaine

(B) Hallucinogens of LSD Type

(C) Volatile Solvents: "Glue".

(D) Cannabis Sativa: Marihuana, hashish

(E) Nicoline: tobacco

(F) Caffeine: Coffee, tea

All drugs used non-medically affect the central nervous system, are taken to alter mood or perception, to cause stimulation, or to allay anxiety or psychic tension.

The classification in Table IV divides drugs used non-medically into three major types: Type I includes those substances that can cause severe physical as well as psychic dependence; Type II includes those that cause only mild or questionable physical dependence, but strong psychic dependence; and Type III includes those that cause only psychic dependence. Type I drugs are further subdivided into subgroups: I-A, the morphine type and I-B the alcohol-borbiturate type. ${ }^{3}$

The classification has practical clinical importance. Patients with moderate to severe grades of physical dependence on types I-A and I-B drugs require withdrawal treatment, whereas those listed under types II and III do not. Furthermore, the drugs listed under types I-A and I-B are interchangeable within the subgroup, regardless of chemical structure, but type I-A drugs are not interchangeable with drugs of type I-B, and type II and II drugs are not interchangeable with type I drugs.

Thus, in type I-A, the morphine type, methadone can be substituted for heroin, and morphine for meperidine, with satisfactory suppression of symptoms of absti- 
nence of the opiate type. In type I-B, the alcohol-barbiturate type, paraldehyde, chlordiazepoxide etc. can be substituted for alcohol, glutethimide for meprobamate etc. ${ }^{3}$ These facts are evidence of cross-tolerance and cross-dependence within the subgroups and are interpreted as indicating that the drugs within the subgroups are pharmacologically related despite differences in chemical structures and some differences in pharmacological action. ${ }^{3}$

In contrast, however, barbiturates, or any drug of type II-A, will not suppress abstinence from opiates and are of no specific value in withdrawing opiates. Likewise morphine or methadone will do nothing for abstinence of the alcohol-barbiturate type. The classification sinplifies withdrawal treatment, since it is only a matter of learning to use only one drug in subgroups I-A and I-B on withdrawal of any agent in the respective subgroups. Thus, methadone can be used for withdrawing any opiate type drug and pentobarbital or chlordiazepoxide (Librium ${ }^{\circ}$ ) for withdrawing any drug of the alcohol-barbiturate type.

The drugs of type II cause only nild or questionable physical dependence, so that withdrawal treatment is not required. Physical dependence on pentazocine may represent a variant of opiate-type dependence and according to Isbel1 ${ }^{3}$ may be misclassified under II. Heavy intravenous use of amphetamines is associated with a definite sequence of symptoms (an abstinence syndrome) but as yet no specific distinctive pathological or neurophysiological change has been demonstrated. ${ }^{3}$ Thus, anphetamines might well be classed with cocaine as central stimulants which do not cause physical dependence. The type II classification is used to indicate the present uncertainties about these drugs.

Drugs of type III cause psychic dependence only and no withdrawal treatment is required.

\section{Problems from Druc Abuse in Association with Anaesthesia}

Recently, there has been a great emphasis on drug abuse in colleges and in middle- and upper-class communities. Marihuana, amphetamines, and barbiturates, rather than opiates, are the drugs most commonly abused by this group. ${ }^{3,10-23}$

Narcotic addicts have a wide range of personality characteristics, with 7 per cent to 10 per cent having psychopathological personality disorders. ${ }^{11,22}$ Table V summarizes some characteristics of age and sex distribution of the criminal addict population in Canada. ${ }^{22}$

TABLE $V$

Sex and Age Characteristics of THE CRIMINal (Narcotic) AdDict Population*

\begin{tabular}{cr}
\hline \multicolumn{1}{c}{ Characteristic } & Per cent \\
\hline Sex: Male & 68.9 \\
Fenale & 31.1 \\
Age: Under 20 & 1.5 \\
$20-29$ & 27.6 \\
$30-39$ & 30.4 \\
$40-49$ & 17.3 \\
$50-59$ & 7.5 \\
60 and older & 4.2 \\
Unknown & 11.5 \\
\hline
\end{tabular}

* Marihuana cases not included. 
The narcotic addict is described as emotionally unstable, immature, impulsive, unreliable, angry against society, unable to establish long-range goals, and unable to meet the demands of his environment. Most narcotic addicts bave a low tolerance for pain, anxiety, frustration, discomfort and distress. On a personality basis alone these are difficult patients to deal with.

There are other problems of drug abuse in association with anaesthesia, as well. The problems encountered may be summarized under the following seven main aspects (Tab]e VI):

(1) Personal injury (self and operating room personnel).

(2) Withdrawal syndromes: unrecognized or improperly managed.

(3) Interactions of abused drugs with andesthetics and adjunctive drugs.

(4) Tolerance.

(5) Dependence: Iatrogenic, induced by the liberal, prolonged, or injudicious use of stimulants or depressants.

(6) Organic changes; chronic intake.

(7) Complications of the needle.

TABLE VI

Drug Aguse and Anaesthetic Problems

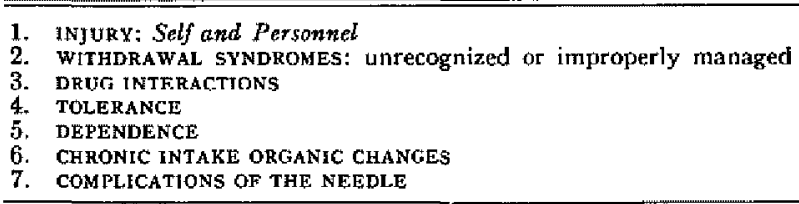

Drug dependence is often unrecognized because patients entering hospitals wilfully withhold history of abuse. Failure to recognize drug dependency may lead to fatal sequelae following abrupt withdrawal of abused drugs. The syndrome may aggravate an existing disease or may result in additional self or personnel injury. ${ }^{28}$

Some of the more salient problems and their anaesthetic implications are summarized in Tables VII to XV, and will be discussed.

(I) (A) Opiate or Morphine Type (Heroin) (Tables VII, VIII)

A fantastic degree of tolerance to opiates can be developed. Cases are on record of persons taking up to $5 \mathrm{gm}$ of morphine in 16 hours. ${ }^{3}$ The pharmacological effects are not always the worst aspects of these drugs, but the fact that they are injected, usually intravenously, leading to the complications of the needle. This accounts for a large percentage of the high death rate. ${ }^{3}$

Acute abstinence from opiates is not dangerous to life; convulsions and delirium do not occur, and treatment is simple. Although any of the type I-A (Table IV) drugs can be used for this purpose, methadone ${ }^{24}$ is best because it is very effective orally and has a long duration of action. Physical dependence on opiates is a real physiological but reversible disorder in the central nervous system, which is basically due to the development of hyperirritability in multineuronal arcs..$^{25}$

Substitution of methadone for whatever opiates or opiaids the patient has 
TABLE VII

Drug Abuse and Anaestuetic Problems

\begin{tabular}{|c|c|}
\hline DRUG & Opiate Type (Morphine) \\
\hline $\begin{array}{l}\text { CHARACTERISTICS } \\
\text { OF INTOXICATION }\end{array}$ & $\begin{array}{l}\text { Coma, miotic pupils, constipation, muscle tremors, } \\
\text { respiratory depression, hypotension }\end{array}$ \\
\hline $\begin{array}{l}\text { TOLERANCE AND } \\
\text { DEPENDENCE }\end{array}$ & Severe \\
\hline $\begin{array}{l}\text { CHARACTERISTICS } \\
\text { OF WITHDRAWAL }\end{array}$ & $\begin{array}{l}\text { Fatigue, weakness, yawning, lacrimation, rhinorrhea, } \\
\text { perspiration, fever, diarrhoea, dehydration. Anta- } \\
\text { gonists may precipitate an abrupt and fatal with- } \\
\text { drawal syndrome in addicts }\end{array}$ \\
\hline \multirow[t]{2}{*}{$\begin{array}{l}\text { ANAESTHETIC } \\
\text { IMPLICATIONS }\end{array}$} & $\begin{array}{l}\text { No significant cross tolerance to anaesthetics. Unilike } \\
\text { chronic alcoholic, no prolonged second stage }\end{array}$ \\
\hline & TABLE VIII \\
\hline \multicolumn{2}{|c|}{ Drug Abuse and Anagsthetic Problems } \\
\hline DRUG & Heroin \\
\hline $\begin{array}{l}\text { CHARACTERISTICS } \\
\text { OF INTOXICATION }\end{array}$ & $\begin{array}{l}\text { Same as morphine with euphoria marked. Exact dose } \\
\text { dificult to determine due to dilution with inert sub- } \\
\text { stances. These may pass into the lung (talc) and } \\
\text { cause pulmonary/perfusion dystunction }{ }^{18}\end{array}$ \\
\hline $\begin{array}{l}\text { TOLERANCE AND } \\
\text { DEPENDENCE }\end{array}$ & Pronounced \\
\hline $\begin{array}{l}\text { CHARACTERISTICS } \\
\text { OF WITHDRAWAL. }\end{array}$ & Similar to morphine \\
\hline $\begin{array}{l}\text { ANAESTHETIC } \\
\text { IMPLICATIONS }\end{array}$ & $\begin{array}{l}\text { Induction of anaesthesia, unlike that of chronic alco- } \\
\text { holics, is "smooth", if pre-medicated with adequat } \\
\text { doses of cross-tolerant drugs, in fractions for pre- } \\
\text { medication and post-operative pain relief, until } \\
\text { desired effect is obtained. Use non-narcotic pre- } \\
\text { medicants for "cured addicts". Veins of ten scle- } \\
\text { rosed. Fluids difficult to administer. Hepatitis? }\end{array}$ \\
\hline
\end{tabular}

been taking followed by reduction of the methadone over a period of days is now the most widely used method of withdrawing opiates.

\section{(B) Alcohol-Barbiturate Type (Tables IX, X, XI)}

Physical dependence occurs in this instance and in contrast to the opiate type abrupt withdrawal is dangerous to life. It must be prevented or treated vigorously. , $^{3,28}$

Physical dependence is due to central nervous system derangement and is not psychogenic. The basic general change may be prolongation of afterdischarge of neurones of many types or enhancement of the supernormal phase of excitability, which has been attributed to "chemical denervation sensitivity". The process is reversible. ${ }^{a}$

Since the type I-B drugs (Table IV) are interchangeable, any of them can be used for withdrawal treatment. The dose of whatever drug is used must initially be sufficient to maintain a mild degree of intoxication (the stabilization dose). This dose must be determined individually by trial and error. Once the stabilization dose is known, it is reduced cautiously over a period of three to twenty-one days, depending on the amount of the stabilization dose and 
TABLE IX

Druki Abuge and Anaesthetic Proflems

\begin{tabular}{|c|c|}
\hline DRUG & Alcohol-barbiturate type: ethyl alcoho] \\
\hline $\begin{array}{l}\text { CHARACTERISTICS } \\
\text { OF INTOXICATION }\end{array}$ & $\begin{array}{l}\text { ACUTE profound physiological and metabolic dis- } \\
\text { turbances-reduced cardiac efficiency. Respiratory } \\
\text { depression. Overlydration. Retention of K+ and } \\
\mathrm{Na}^{+} \text {conmono Intracellular, interstitial, plasma } \\
\text { fuid volume and total body water are increased. } \\
\text { ADH decreased during uptake. Diuresis common. } \\
\text { Anti-diuresis when blood level stabilized. Leuko- } \\
\text { penin. Hyperlipatemia }\end{array}$ \\
\hline \multicolumn{2}{|l|}{$\begin{array}{l}\text { TOLERANCE AND } \\
\text { DEPENDENCE }\end{array}$} \\
\hline $\begin{array}{l}\text { CHARACTERISTICS } \\
\text { OF WITHDRAWAL }\end{array}$ & $\begin{array}{l}\text { Delirium and excitement uncommon, but may de- } \\
\text { velop as blood level falls }\end{array}$ \\
\hline $\begin{array}{l}\text { ANAESTHETIC } \\
\text { IMPLICATIONS }\end{array}$ & $\begin{array}{l}\text { Additive with anaesthetics. Predisposes to over- } \\
\text { dosage. Intoxica ted patient, apart from disorienta- } \\
\text { tion resalting in self injury or personnel injury, not } \\
\text { resistat to antesthesia. Full stomach predisposes } \\
\text { to vomiting and aspiration. Restrict intravenous } \\
\text { fuids }\end{array}$ \\
\hline
\end{tabular}

TABLE $X$

Drug Abuse and Anaesthetic Problems

\begin{tabular}{|c|c|}
\hline DRUO & Etsyl alcohol \\
\hline $\begin{array}{l}\text { CHARACTERISTICS } \\
\text { OF INTOXICATION }\end{array}$ & $\begin{array}{l}\text { CHRONIC: Fat metabolism altered with subsequent } \\
\text { hepatic damage }\end{array}$ \\
\hline $\begin{array}{l}\text { TOLERANCE AND } \\
\text { DEPENDENCE }\end{array}$ & Severe \\
\hline $\begin{array}{l}\text { CHARACTERISTICS } \\
\text { OF WITHDRAWAL }\end{array}$ & $\begin{array}{l}\text { Dejirium tremens most common problem. Mortality } \\
\text { ranges from } 10 \text { to } 50 \text { per cent }\end{array}$ \\
\hline \multirow[t]{2}{*}{$\begin{array}{l}\text { ANAESTHETIC } \\
\text { IMPLICATIONS }\end{array}$} & $\begin{array}{l}\text { Additive and cross tolerant with general anaesthetics. } \\
\text { Increased dosage of anacsthetics required. Serious- } \\
\text { ness of delirium tremens (abstinence syndrome) not } \\
\text { always fully appreciated }\end{array}$ \\
\hline & $\begin{array}{l}\text { Management: Minimize stimuli of all types (auditory, } \\
\text { optical, tactile). Avoid restraints, instrumentation, } \\
\text { venipuncture, catheterization etc. Use psychoseda- } \\
\text { tives (chlordiazepoxide (Librium(G) or diazepam } \\
\text { (Valium(B)) or hydroxyzine (Vistaril(B) to reduce } \\
\text { motor activity. Avoid barbiturate and non-barbi- } \\
\text { turate hypnotics since excessive and dangerous } \\
\text { quantities are required. Also, cross-tolerance de- } \\
\text { velops. Investigate and appreciate associated } \\
\text { organic diseases, e.g. myocarditis, hepatic dys- } \\
\text { function, } G \text {.I. bleeding, hypomagnesaemia, etc. }\end{array}$ \\
\hline
\end{tabular}

response. Paraldehyde is a classic drug and is effective, although unpleasant. Chlordiazepoxide and diazepam are currently popular and probably effective. ${ }^{2}$ Some prefer pentobarbitone. ${ }^{26}$

If the patient has had a convulsion or is delirious, he should be reintoxicated rapidly with one of the group I-B (Table IV) drugs to a degree sufficient to induce sleep, after which the stabilization dose is determined and gradual reduction carried out as before. ${ }^{26}$ 
TABLE XI

Drug Abuse and Anaesthetic Problems

\begin{tabular}{|c|c|}
\hline DRUG & Barbiturate \\
\hline $\begin{array}{l}\text { CHARACTERISTICS } \\
\text { OF INTOXICATION }\end{array}$ & Respiratory, cardiovascular depression \\
\hline $\begin{array}{l}\text { TOLERANCE AND } \\
\text { DEPENDENCE }\end{array}$ & Very strong psychic and physical dependence \\
\hline $\begin{array}{l}\text { CHAKACTERISTJCS } \\
\text { OF WITHDRAWAL }\end{array}$ & $\begin{array}{l}\text { Anxiety, tremors, weakness, insomnia, beadache, } \\
\text { twitchings, nervousness, delisium, initially during } \\
\text { first } 24 \text { hours: later, orthostatic hypotension, } \\
\text { vomiting and convulsions (grand mal type) }\end{array}$ \\
\hline \multirow[t]{2}{*}{$\begin{array}{l}\text { ANAESTHETIC } \\
\text { IMPLICATIONS }\end{array}$} & $\begin{array}{l}\text { Abstinence syndrome similar to alcohol. Cas be ser- } \\
\text { ious and life threatening. }\end{array}$ \\
\hline & $\begin{array}{l}\text { Management: Continue administration of abused drug } \\
\text { but gradually withdraw and substitute non-habit } \\
\text { acting psychosedatives (tranquilizers) e.g. pheno- } \\
\text { thiazines }\end{array}$ \\
\hline
\end{tabular}

It is important to realize that the "major tranquillizers" (e.g. chlorpromazine) will not suppress abstinence (withdrawal) of the alcohol-barbiturate type and actually, if used alone, increase mortality. ${ }^{27,28}$

(II) (A) Opiate Agonist-Antagonist Type

It is now known that the narcotic antagonists, nalorphine, levallorphan, and cyclazocine, have morphine-like (agonistic) actions as well as antagonistic effects. All these drugs will, when given chronically, create a mild type of physical dependence similar to but not identical with abstinence from morphine. ${ }^{29}$ Pentazocine is a relatively potent agonist and hence an effective analgesic, but a weak antagonist. The result is that pentazocine is a drug of dependence even though it has never been controlled by the Federal Narcotic Law. It now seems evident that any narcotic antagonist with analgesic properties will produce this kind of dependence. ${ }^{3}$

(B) Amphetamine Type (Table XII)

Any of the type II-B (Table IV) drugs, or a mixture of them, can be involved. They act at peripheral adrenergic sites chiefly by displacing norepinephrine from storage granules. All are potent CNS stimulants, causing elation,

TABLE XII

Drug Abuse and Anaesthetic Problems

\begin{tabular}{lc}
\hline DRUG & Amphetamine type \\
CHARACTERISTICS & Tend to be accident prone from excitation or fatigue \\
OF INTOXICATION & (see also cocaine) \\
TOLERARCE AND & Induce tolerance with slow onset. Physical depen- \\
DEPENDENCE & dence uncommon \\
CHARACTERISTICS & Withdrawal is not symptomless. Psychotoxic effects. \\
OF WITHDRAWAL. & Long sleep, hunger, apathy and depression may \\
result & Psychoses with paranoid manifestations. Increased \\
hanATHETIC & halothane required to achieve MAC
\end{tabular}


alleviation of fatigue, insomnia and anorexia. The cause of the central effects is unknown but is postulated to be displacement of catecholamines from storage sites within the CNS, similar to that which occurs at the periphery. Although still widely used as anorexiants for the treatment of obesity, the only remaining proven medical uses for these drugs are in narcolepsy and in the treatment of hyperkinetic children. ${ }^{30}$

Characteristically, amphetamine abuse tends to be mixed with dependence on opiates, hypnotics, or alcohol.

As long as the daily dosage is low ( $40 \mathrm{mg}$ or less of dextroamphetamine or the equivalent amount of another drug ), little known danger results. If the dose is increased, the chief danger is the development of a psychotic state resembling paranoid schizophrenia, which clears rapidly when the drug is stopped $^{30,31}$

A definite sequence of symptoms ensues when heavy amphetamine use is terminated. First, the patient falls into a deep sleep, lasting for a day or two. During this period, rapid-eye-movement (REM) sleep, which is associated with dreaming and which was suppressed by amphetamines, occurs. ${ }^{32}$ After the period of sleep, the "freak" is ravenously hungry and eats tremendous amounts of food. A period of apathy and depression then follows, during which suicide may occur, or the depression is likely to initiate another "run".

Heavy intravenous amphetamine abuse has to be ranked along with alcohol and intravenous use of opiates as one of the most catastrophic forms of drug abuse. Damage to the individual's health, personal relationships and ability to function in society are common. Additional complications are those associated with the needle, including infections and sudden death. The death rate among "speed freaks" approaches that of intravenous opiate users. ${ }^{\text {as }}$

Withdrawal treatment is not necessary. If the patient is psychotic, the phenothiazine tranquilizers may be given. Usually all that is required is to protect the patient and let the syndrome run its course. The typical apathy and depression are especially difficult to handle.

(III) (A) Cocaine (Table XIII)

In North America cocaine is a favourite drug of sociopaths who take it intravenously, frequently in combination with heroin (The Speedball), for its

TABLE XIII

Drug Abuse and Anaesthetic Problems

\begin{tabular}{|c|c|}
\hline DRUG & Cocaine \\
\hline $\begin{array}{l}\text { CHARACTERISTICS } \\
\text { OF INTOXICATION }\end{array}$ & $\begin{array}{l}\text { May resemble amphetamines. Enotional lability, loss } \\
\text { of appetite, mental impairment, tachycardia, di- } \\
\text { lated pupils, hypertension, hyperreflexia, tremors } \\
\text { and convulsions }\end{array}$ \\
\hline $\begin{array}{l}\text { TOLERANCE AND } \\
\text { DEPENDENCE }\end{array}$ & Psychic dependence only \\
\hline $\begin{array}{l}\text { CHARACTERISTICS } \\
\text { OF WITHDRAWAL }\end{array}$ & $\begin{array}{l}\text { Psychotoxic mania, delirium, delusions, hallucina- } \\
\text { tions }\end{array}$ \\
\hline $\begin{array}{l}\text { ANAESTHETIC } \\
\text { IMPLICATIONS }\end{array}$ & $\begin{array}{l}\text { Sedated patients not difficult to anaesthetize. iNo } \\
\text { cross-tolerance with anaesthetics }\end{array}$ \\
\hline
\end{tabular}


central stimulating effect. Like the amphetamines, cocaine is an indirectly acting sympathomimetic amine, but exerts its effect by preventing uptake of norepinephrine by nerve endings rather than by displacing catecholamines from storage sites. The clinical manifestations are similar to those of intravenous amphetamines, but the development of the paranoid psychotic state (the "bull horrors") is more rapid. In addition, tolerance to cocaine is thought not to occur. ${ }^{34}$

\section{(B) Hallucinogens of the LSD Type (Table XIV)}

Psychic dependence on hallucinogens differs from psychic dependence on other drugs in that, except for initial experimentation, the drugs are not taken daily but occasionally. These drugs are particularly attractive to young persons of Bohemian habits ("hippies") who are in rebellion against the establishment. Those who become regular users take the drug in the hope of attaining transcendental mystic experiences which will give them greater understanding of themselves, the world and the universe. ${ }^{35}$ Frequently they become interested in and join the mystic religions of the Orient.

TABI.E XIV

Drug abuse and Anaesthetic Problems

\begin{tabular}{|c|c|}
\hline DRUG & $\begin{array}{l}\text { Hallucinogenic type: L.S.D. (Lysergic Acid Diethyl- } \\
\text { amide) }\end{array}$ \\
\hline $\begin{array}{l}\text { CHARACTERISTICS } \\
\text { OF INTOXICATION }\end{array}$ & $\begin{array}{l}\text { Hallucinations, disorientation, lack of judgement, } \\
\text { leading to injury. Feeble analgesic action. Poten- } \\
\text { tiates narcotic analgesics. May precipitate psy- } \\
\text { chosis in pre-psychotics }\end{array}$ \\
\hline $\begin{array}{l}\text { TOLERANCE AND } \\
\text { DEPENDENCE }\end{array}$ & Psychic dependence strong. No physical dependence \\
\hline $\begin{array}{l}\text { CHARACTERISTICS } \\
\text { OF WITHDRAWAL }\end{array}$ & $\begin{array}{l}\text { Potentiates narcotic analgesics. No tolerance or cross- } \\
\text { tolerance to anaesthetics. Induction and main- } \\
\text { tenance of anaesthesia usually uneventf ul in se- } \\
\text { dated patients; but, mild degree of anticholine- } \\
\text { sterase activity (in chronic user). Prolongation of } \\
\text { succinylcholine block and interference with detoxi- } \\
\text { fication of local anaesthetics (ester type). Interferes } \\
\text { with activity of monoamine oxidase inhibitors. } \\
\text { Augments action of sympathomimetic amines, in- } \\
\text { terferes with metabolism of bistamine (broncho- } \\
\text { spasm) and serotonin and prolongs their effects. } \\
\text { Psychotic episodes may occur months after with- } \\
\text { drawal or appear in the post-operative period. }\end{array}$ \\
\hline
\end{tabular}

These compounds are taken orally and rarely by injection. Generally, hallucinogens are taken in company with other persons in a setting utilizing garish colours, lights, strips of foil, etc. One or more persons usually abstain from the drug in order to observe and protect the others ("trip conductor or guide").

The effects of these drugs are dose related. Thus, a "bad trip" will always occur if the dose is sufficiently large. ${ }^{30}$

These compounds cause signs of adrenergic stimulation, such as increased temperature, dilated pupils, increased blood pressure, and increased concentrations of free fatty acids in serum. These changes are due to central hypo- 
thalamic stimulation rather than to effects on peripheral adrenergic mechanisms, in contrast to the peripheral actions of cocaine and amphetamines. In addition LSD impairs mechanisms within the brain that normally enable a person to suppress and ignore most of the continuous flood of relatively unimportant sensory stimuli he is receiving and to pay attention only to those sensations important at the moment. ${ }^{30}$ Thus, the individual who has taken LSD becomes submerged in a torrent of sensations that he cannot ignore. Sounds seem louder, colours brighter. The individual's own body may seem altered ("depersonalization").

"Bad trips" are usually readily handled by placing the patient in a quiet, darkened room, and giving quiet sympathetic support. If any drug is used, a phenothiazine tranquilizer is the most rational choice. ${ }^{30}$

(C) Volatile Solvents ("Glue") (Table XV)

All of these solvents are in effect general anaesthetics and cause excitation and drunkenness. The chief danger is suffocation by the inhaler slumping face down into the plastic bag. Although most of the solvents are hepatotoxic and renal toxic, liver and kidney damage seldom occur.

TABLE XV

Drug Abuse and Anaesthetic Problems

\begin{tabular}{|c|c|}
\hline DRUG & Volatile Solvents \\
\hline $\begin{array}{l}\text { CHARACTERISTICS } \\
\text { OF INTOXICATION }\end{array}$ & $\begin{array}{l}\text { Similar to general anaesthetics. Drowsiness, and } \\
\text { stupor. May have mental aberrations, euphoria, } \\
\text { and hallucinations. Coma and respiratory failure } \\
\text { with overdose }\end{array}$ \\
\hline $\begin{array}{l}\text { TOLERANCE AND } \\
\text { DEPENDENCE }\end{array}$ & Psychic dependence only \\
\hline \multicolumn{2}{|l|}{$\begin{array}{l}\text { CHARACTERISTICS } \\
\text { OF WITHDRAWAL }\end{array}$} \\
\hline $\begin{array}{l}\text { ANAESTHETIC } \\
\text { IMPLICATIONS }\end{array}$ & $\begin{array}{l}\text { Personal injury may result during intoxication. } \\
\text { Liver, bone marrow, kidney and other organs may" } \\
\text { be damaged in chronic "snifers". }\end{array}$ \\
\hline
\end{tabular}

(D) Cannabis Sativa (Marihuana, Hashish)

The use of marihuana is being hotly debated in Canada and United States and other western countries. On one side, the proponents argue that marihuana is a mild euphoriant, less harmful than alcohol, and that marihuana should be legalized and sold under regulation. On the other hand, the opponents of marihuana agree that it is a dangerous drug, leading to anti-social behaviour, criminal assaults, and insanity. The majority of the public is confused. An acknowledged fact, though, is that experimentation with marihuana and hashish is increasing rapidly, particularly among college and high school students. ${ }^{3+, 37}$

Although non-medical use of cannabis is one of the oldest and most widespread intoxications in the world, less is known about it than about any other kind of intoxication. The chief reason for this relative ignorance has been the very difficult chemistry of cannabis. The bemp plant secretes a resin which 
contains the active principles, which are not soluble in water and which do not crystallize. ${ }^{30}$ The exact molecular configuration of the most active constituents of hemp resin, the 3,4-trans-tetrahydrocannabinals (THCS) were not established exactly until $1965^{38}$ and total synthesis of these compounds was not achieved until $1967 .{ }^{30}$

As a result of these preparations now becoming available for objective scientific study, new information is beginning to pour in from a variety of programmes. ${ }^{40}$

Since the potency of most U.S. and Canadian marihuana is low, intoxication is usually mild. Serious reactions might become more frequent if more potent materials become available.

The clinical manifestations of marihuana intoxication are subtle, diffcult to detect, and depend on the setting, the expectations of the individual, ${ }^{37,41}$ and, most important, on the amount of THCS ingested ${ }^{42}$ and the rapidity of ingestion.

The possibility of damage to the central nervous system due to cannabis cannot yet be disproved. ${ }^{30}$

Marihuana smokers practically never request treatment, since they do not believe they have anything wrong with them. Most "bad trips" from marihuana are panic reactions ${ }^{43}$ and are usually handled by the smoker's friends. Basic care involves protection of the patient, quiet reassurance, and presence of a friend whom the smoker can trust. If drugs are used at all, the phenothiazine tranquilizers should be avoided, since they may add to the tendency to postural hypotension. Chlordiazepoxide or diazepam would be safer and better choices.

There is an increasing likelihood that the practicing anaesthetist will be faced with the patient who has taken drugs in a manner which would be considered abuse, prior to coming to surgery. ${ }^{44}$ The anaesthetist is faced with the problem of identifying the abuser and of identifying the type of drug he abuses and its anaesthetic implications; with anticipating possible interactions between the abused drug or drugs and the various pharmacological agents used to produce anaesthesia. He must be prepared to deal with the problem of initial emergency management of withdrawal (abstinence syndrome) preoperatively or post-operatively, and the treatment of drig overdose (acute intoxication).

\section{SUMMANY}

New concepts have recently developed, in the consideration of Drug Abuse ${ }^{3}$ (Non-medical Use of Drugs) not only in alterations of terminology but also in the depth and variety of understanding of the pharmacological and social problems that accompany the currently prevalent trend to increase of such abuse of drugs.

Because of this trend, there is an increasing likelihood that the practicing anaesthetist will be faced with patients who have taken drugs prior to coming to surgery and anaesthesia in a way which would be considered abuse of these substances.

There are problems from drug abuse in association with anaesthesia. The anaesthetist may have not only the problem of identifying the abuser but also of identify- 
ing the type of drug he abuses and its anaesthetic implications. These implications generally fall into seven main aspects:

(1) Personal injury (self and O.R. personnel).

(2) Withdrawal syndromes: unrecognized or improperly managed.

(3) Interactions of abused drugs with anaesthetics and adjunctive drugs.

(4) Tolerance.

(5) Dependence: Iatrogenic, induced by the liberal, prolonged, or injudicious use of stimulants or depressants.

(6) Organic changes; chronic intake.

(7) Complications of the needle.

\section{RÉsumér}

Dernièrement, il est apparu de nouvelles conceptions sur l'interprétation de l'abus de drogues (usage non médical de médicament), et, cela, non seulement en ce qui concerne les modifications de la terminologie, mais, aussi, dans la variété et la profondeur de la compréhension des problêmes sociaux et pharmacologiques qui accompagnent la tendance croissante actuelle de l'abus de ces drogues.

A cause do cette tendance, il est vraisemblable que l'anesthésiste, de plus en plus, aura à rencontrer des malades qui ont pris, avant d'être amenés à la chirurgie et à lanesthésie, des drogues de façon que l'on peut qualifier: abus de drogues.

Ces abus posent des problêmes a l'approche de l'anesthésie. L'anesthésiste peut avoir non seulement à identifier le malade qui abuse mais en plus à identifier la drogue utilisée et ses implications avec l'anesthésie. Ces implications, en général, se rangent dans sept aspects principaux:

(1) Blessures corporelles (soit personnelles soit par le personnel des salles d’opération).

(2) Syndrome du silence: méconnu ou mal traité.

(3) Interactions des drogues avec les agents anesthésiques et les médicaments associés.

(4) La résistance.

(5) La création d'habitude d’origine iatrogénique à cause de l'usage libéral, prolongé et non judicieux de stimulants et de dépresseurs.

(6) Changements organiques: absorption chronique.

(7) Complications des injections.

\section{REFERENCES}

1. Goopman, L.S. \& Guman, A. (eds.) The Phamacological basis of therapeutics. Ed. 4, New York, Macmillan Co. (1970).

2. Long, R.E. \& Penna, R.P. Drugs of abuse. J. Amer. Pharmaceutical Assn. Vol. 58, No. 1: 12-14 (Jan.) (1968).

3. Isberl, $H$. Clinical aspects of the various forms of nonmedical use of drugs. Part $I$. Anesthesia and Analgesia Current Besearches 50:880-896 (1971).

4. Bunss, J.J. \& Cor,NEx, A.Y. Enzyme stimulation and inhibition of the metabolism of drugs. Proc. Roy, Soc. Med, 58: 955-960 (1965). 
5. CoHEN, M., KEATS, A.S., \& DRTWAY, W. Effect of actinomycin-D on morphine tolerance. Proc. Soc. Exp. Biol. Med. 119: 381-383 (1965).

6. LOH, H., SHEN, F, \& WAY, E.L. Effects of cyclohexinide on the development of morphine tolerance and physical dependence. Pharmacologist 2: 192 (1968).

7. Cochn, J. Factors in the blood of morphine tolerant animals that attenuate or enhance the effects of morphine. Res. Publ. Res. Nerve Ment. Dis. 46: 268-279 (1968).

8. MARTIN, W.R, A homeostatic and redundancy theory of tolerance to and dependence on narcotic analgesics. Res. Publ. Assoc. Res. Nerve Ment. Dis. 46: 206-225 (1968).

9. JAFFe, J.H. \& Sharpless, S.K. Pharmacological denervation sensitivity in the central nervous system: a theory of physical dependence. Res. Publ. Assoc. Res. Nerve Ment. Dis. 46: $226-246$ ( 1968 ).

10. Commission of Inguiry into the Non-Medical Use of Drugs, Interim Report. Ottawa, Ontario, Canada, Queen's Printer (1970).

11. Patterns: Drug Abuse: \#2 (1971), Publ. Parke, Davis \& Co. Ltd.

12. Appendices to the Nineteenth Annual Report (1969) of the Alcoholism and Drug Addiction Research Foundation, Ontario: Addiction Research Foundation (1970).

13. Helperin, M. \& Rho, Y. Deaths from narcotism in New York City. Incidence, circumstances and post-mortem findings. New York State J. Med. 66: 2391 (1966).

14. Saptra, J.D., Jasinski, D.R., \& GononeTzsky, C.W. Liver disease in narcotic addicts. The role of the needle. Clin. Pharmacol. Ther. 9: 725-739 (1963).

15. Lourua, D.B., Hensle, $T$., \& Hose, J. The major medical complications of heroin addiction. Ann. Intern. Med. 67: 1-22 (1967).

16. Termansen, R.E., Harrts, R.E., Bhoome, A. Sulcide and attempted suicide in Vancouver, B.C., Canada (unpublished data) (1972).

17. SMant, R,G., Fejen, D., \& White, J. The extent of drug use in Metropolitan Toronto schools. A study of changes from 1968 to 1970. Education Division, Addiction Research Foundation, Toronto (1970).

18. Adhiani, J. Zepernick, R.G., Eckert, C.E., \& Graulau, M.F. Ptoblems in surgical patients due to drug abuse and dependence: types, recognition, differential diagnosis and management. Exhibit: Convention AMA Chicago, Ill., June 21 (1970).

19. Wilson, C.W.M. Adolescent drug dependence, Pergamon Press (1967)

20. Policy statement on narcotics addiction, 159th Annual Meeting of the House of Delegates of the Medical Society of the State of New York, Feb. (1965).

21. Hess, C.B. New trends in narcotic addiction control. Public Health Rep. 81 : 277 (1966).

22. Data from the Division of Narootic Addiction Control. Public Hentth and Welfare Pub. (1969) Queen's Printer.

23. JoHnston, R.R., WAY, W.L., \& MILLER, R. Alteration in anaesthetic requirements with amphetamines, Abstracts A.S.A. Annual Meeting, New York (Oct.) (1970)

24. IseELI, H. \& VogeI, V.H. The addiction liability of methadone (amidone, dolophine, 10820 ) and its use in the treatment of the morphine abstinence syndrome. Amer. J. Psychiat. 105: 900-914 (1949).

25. WIKLER, A. Recent progress in research on the neưophysiologic basis of morphine addiction. Amer. J. Psychiat. 105: 329-358 (1948).

26. IseELI, $\mathbf{H}$. Diug dependence, addiction and intoxication. Cecil-Loeb: Textbook of Medicine, 12th ed. Ed. P.B. Beeson, W. McDermott, Philadelphia, W.B. Saunders Co. (1967) pp. 1494-1504.

27. KaIN, S.C., KLETT, C.J., \& RothFet,o, B. Treatment of acute alcohol withdrawal state: a comparison of 4 drugs. Amer. J. Psychiat. 125: 1640-1646 (1969).

28. Thomas, D.W. \& FREEMAN, D.X. Treatment of the alcohol withdrawal syndrome: comparison of promazine and paraldehyde. J.A.M.A. 188: 316-318 (1964).

29. EDDY, N.B. \& MARTIN, W.R. Drug dependence of specific opiate antagonist-type: Pharmackopsychiat. Neuropsychopharmakol. 3: 73-82 (1970).

30. IsBezL, H. Clinical aspects of the vatious forms of non-medical use of drugs, Part II. Aresthesia and Analgesia Curr. Res, 50: 897-905 (1971).

31. Kramer, J.C., Fishman, V. \& Littlefield, D.C. Amphetamine abuse. Pattern and effect of high doses. J.A.M.A. 201:305-309 (1969).

32. OsWALD, I. \& THACore, V.R. Amphetamine and phenmetrazine addiction: physiological abnomalities in the abstinence syndrome. B. Med. J. 2: 427-431 (1963).

33. Goldaerc, L. Drug abuse in Sweden, Part I. U.N. Bull. Narcot. 20: 9-36 (1968).

34. EDdy, N.B., HaLbach, $H$. Is IselL, $H$. Drug dependence; its significance and characteristics. Bull WHO 32: 72\&-733 (1965). 
35. Conen, S. The beyond within the LSD story. New York, Atheneum (1964).

36. BuUM, R.H. Drugs II. Students and drugs. San Francisco, Jossey-Blass (1969).

37. Brul., N.Q., Crumprom, E., \& Frank, I.J. The marihuana problem. Ann. Intern. Med. 73: $449-465(1970)$

38. GAONI, Y. \& MECHOULAM, R. A total synthesis of dl- delta-1-tetrahydrocannabinol, the active constituent of hashish. J. Amer. Chem. Soc. 87; 3273-3275 (1985).

39. Mechoulam, R., Bratu, P., \& Shvo, Y. A stereo specific synthesis of $(-)$ - delta 1 and (-) (-) delta (1) (6) - tetrahydrocannabinals. J. Amer. Chem. Soc, 89: 45524554 ( 1967 ).

40. MrLen, M. The National Institute of Mental Health Research Program, Bull problems of drug dependence, National Academy of Sciences, National Research Council. Report of 32nd Meeting. February 16-18 (1970), pp. 6386-6393.

41. PIlLAfd, R.C. Medical progress: marihuana. New Eng. J. Med. 263: 294-303 (1970).

42. Isbelx, H., Corodetzkx, C.W., \& JAsINSKR, D.R. Effects of (-)-9,trans-tetrahydrocannabinal in man. Psychopharmacologia 11: 184-188 (1967).

43. Went, A.T. Adverse reactions to marihuana. New Eng. J. Med. 282; 977-1000 (1970).

44. Way, Walter L. Drug abuse: anesthetic considerations. ASA Refresher Course Book Publ. October (1971) p. 122. 